\title{
GERMINAÇÃO IN VITRO DE DALBERGIA NIGRA VELL. FR. ALL. EX BENTH
}

\author{
João Otávio da Silva Malaquias ${ }^{1}$ \\ Aline Tintori Mantovani ${ }^{2}$ \\ Elias Terra Werner ${ }^{3}$ \\ Geisiele Silva Martins ${ }^{4}$ \\ Renan Carrari dos Santos ${ }^{5}$ \\ Tabatta Caroline Cerri Franca ${ }^{6}$ \\ Mariana Spala Corrêa ${ }^{7}$
}

\begin{abstract}
Resumo: A história do Brasil é inteiramente ligada a espécies nativas que moveram a economia do país por décadas, entre essas espécies está o jacarandá-da-bahia (Dalbergia nigra Vell. Fr. All. Ex Benth), cuja madeira possui alto valor comercial. Sua exploração aliada à falta de manejo levou essa espécie a figurar na lista das espécies ameaçadas de extinção da flora brasileira. Diante do exposto, o objetivo do presente trabalho foi avaliar as condições mais favoráveis à germinação e estabelecimento in vitro de jacarandá-dabahia, a fim de possibilitar posteriormente a micropropagação e produção de plântulas viáveis. As sementes foram submetidas a dois tratamentos para desinfestação, uma com hipoclorito de sódio outro com peróxido de hidrogênio. Foi realizado um teste de germinação com três meios de cultivo (MS, WPM e B5) sendo o delineamento inteiramente casualizado. O tratamento com peróxido de hidrogênio apresentou maior porcentagem de germinação (72\%). Os resultados de Parte Aérea (PA), Comprimento da Raiz (CR), e Massa Fresca (MF) não diferiram estatisticamente. Quanto ao número de folhas, o Meio WPM apresentou maior número de folhas, não distinguindo estatisticamente do Meio B5 (4.31 e 4.15).
\end{abstract}

Palavras-chave: Meio de cultivo; Desinfestação; Cultivo in vitro; Mata Atlântica; Jacarandá-da-bahia.

\footnotetext{
1 Ciências Biológicas joaootaviosm@gmail.com.

2 Ciências Biológicas alinetintori@hotmail.com.

3 Ciências Biológicas eliaswerner12@gmail.com.

4 Ciências Biológicas martinsgeisiele@gmail.com.

5 Ciências Biológicas Licenciatura/Universidade renancarrarisantos@hotmail.com.

6 Ciências Biológicas Licenciatura/Universidade tata_cerri@hotmail.com.

7 Ciências Biológicas marianaspala@gmail.com.

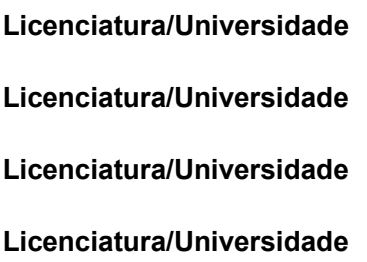

